\title{
The opportunistic feeding and reproduction strategies of the annual fish Cynopoecilus melanotaenia (Cyprinodontiformes: Rivulidae) inhabiting ephemeral habitats on southern Brazil
}

\author{
Cristina da Silva Gonçalves ${ }^{1}$, Ursulla Pereira Souza ${ }^{2}$ and Matheus Vieira Volcan ${ }^{3}$
}

\begin{abstract}
Most Rivulidae fishes are popularly known as annual fishes which live in ephemeral environments such as pools, that obligatorily dry out seasonally causing the death of adult individuals. They have unique biological characteristics such as small body size, early sexual maturation, continuous reproduction, an elaborated courtship behavior, and a great reproductive capacity among fishes. The rivulids are widely distributed in North, Central and South America. In this study, the diet and reproductive biology of Cynopoecilus melanotaenia was analyzed. A total of 263 specimens were collected and the analysis of 233 gastrointestinal contents revealed an invertivorous diet composed mainly of small crustaceans (Cladocera, Amphipoda, and Ostracoda) and immature insects (Chaoboridae, Culicidae, Syrphidae, but mainly Chironomidae larvae). Lepidophagy on male's diet was also registered. Fecundity was estimated by analyzing 59 pairs of mature ovaries and ranged from 2 to 157 oocytes (mean, $19 \pm 26[\mathrm{SD}]$ ). The species has fractional spawning, a strategy to increase the chance of survival to prolonged depletions. This study is the first to investigate the reproductive biology of $C$. melanotaenia. The results confirmed the opportunistic character of the rivulid C. melanotaenia and provided unreported reproductive information that may aid conservation of the species.
\end{abstract}

A maioria dos peixes da família Rivulidae são popularmente conhecidos como anuais por completarem todo seu ciclo biológico em pequenos corpos de água temporários que secam obrigatoriamente em determinados períodos do ano causando a morte dos indivíduos adultos. Possuem características biológicas peculiares como pequeno porte, maturação sexual precoce, reprodução contínua, um elaborado padrão de corte e uma grande capacidade reprodutiva entre os peixes. Os rivulídeos se encontram amplamente distribuídos nas Américas do Norte, Central e Sul. Este trabalho analisou a dieta e a biologia reprodutiva de Cynopoecilus melanotaenia. Foram coletados 263 exemplares e a análise de 233 conteúdos gastrointestinais revelou uma dieta invertívora composta principalmente por microcrustáceos (Cladocera, Amphipoda e Ostracoda) e insetos imaturos (Chaoboridae, Culicidae, Syrphidae, mas principalmente larvas de Chironomidae). Foi registrada a lepidofagia na dieta dos machos. A fecundidade foi estimada pela análise de 59 pares de ovários maduros e variou entre 2 a 157 ovócitos (média, $19 \pm$ 26[DP]). A espécie apresentou desova parcelada, uma estratégia para aumentar a chance de sobrevivência a depleções prolongadas. Este trabalho apresenta a primeira investigação sobre a biologia reprodutiva de C. melanotaenia. Os resultados encontrados sugerem a estratégia reprodutiva oportunista de C. melanotaenia e fornecem novas informações biológicas que podem contribuir para pesquisas de conservação e manutenção da espécie em seu ambiente natural.

Key words: Aplocheiloidei, Diet, Fecundity, Invertivorous, Opportunism.

\footnotetext{
'Programa de Pós-Graduação em Ciências Biológicas, Universidade Estadual Paulista “Júlio de Mesquita Filho”, Departamento de Zoologia. Av. 24-A, 1515, 13506-900 Rio Claro, SP, Brazil. cristina.silva.goncalves@gmail.com

${ }^{2}$ Universidade Estadual Paulista "Júlio de Mesquita Filho", Departamento de Ecologia. Av. 24-A, 1515, 13506-900 Rio Claro, SP, Brazil.

${ }^{3}$ Instituto Pró-Pampa (IPPampa), Laboratório de Ictiologia. Rua Gomes Carneiro, 1043, Centro, 96010-610 Pelotas, RS, Brazil.
} 


\section{Introduction}

The family Rivulidae (Cyprinodontiformes: Aplocheiloidei) comprises 27 genera and approximately 324 valid species distributed in southern North, Central and South America, and it is one of the largest families of freshwater fishes in the Neotropics. They are represented in Brazil by 201 species which accounts for $62 \%$ of all rivulids (Costa, 2008). Most members of this family are popularly known as annual or seasonal fishes which complete their entire life cycle in small temporaries water systems that obligatorily dry out seasonally causing adult death (Costa, 1990a, 2002b). By inhabiting such variable environments, they are exposed to high fluctuations on temperature, oxygen level and food supply (Errea \& Danulat, 2001). Populations survive desiccation through buried eggs in diapause until the next rainy season when the embryos hatch (Wourms, 1972). The rivulids have a short life cycle characterized by fast sexual maturation, continuous reproduction and rapid growth (Arenzon et al., 1999, 2001; Errea \& Danulat, 2001) and their entire life cycle depends on an elaborate courtship behavior and a great reproductive capacity (Costa, 1998).

In addition to its unique biological characteristics, most species have restricted distributions which increase their vulnerability. Furthermore, many of them are threatened by anthropogenic pressures mainly due to habitat loss caused by agriculture, urbanization, deforestation, drainage and embankments (Costa, 2002b, 2008). In Brazil, 52 species are endangered (Rosa \& Lima, 2008) and in the State of Rio Grande do Sul, the rivulids represent about $40 \%$ of all threatened freshwater fish fauna (Reis et al., 2003).

The phylogenetic relationships of the Rivulidae family have been extensively studied (Parenti, 1981; Costa, 1990a, 1995, 1998, 2002a, 2002c; Murphy \& Collier, 1996; Hrbek \& Larson, 1999; Murphy et al., 1999; Costa, 2006a, 2006b; Hertwig, 2007). However, few biological studies have been conducted so far (Arenzon et al., 1999, 2001; Errea \& Danulat, 2001; Shibatta \& Rocha 2001; Shibatta \& Bennemann, 2003; Laufer et al., 2009; Arim et al., 2010; Polaèik \& Reichard, 2010), despite of the great diversity of the family (Costa, 2008) and the extreme vulnerability of some species (Costa, 2002b; Reis et al., 2003; Rosa \& Lima, 2008). The lack of basic information on annual fishes is due, in part, by few ichthyological surveys in environments where these species are exclusively found (Rosa et al., 2003).

The genus Cynopoecilus comprises five endemic species from Brazilian southern coastal plains and eastern Uruguay (Costa, 2002c). In Brazil, the species are restricted to small temporary water bodies and floodplain streams associated to Patos and Mirim Lagoons (State of Rio Grande do Sul), and live in sympatry with Austrolebias spp. (annual fishes) (Costa, 2002b, 2002c). Previous biological studies on Cynopoecilus focused on reproductive aspects (Arenzon et al., 1999), growth (Arenzon et al., 2001), embryonic development (Arenzon et al., 2002) and toxicity (Arenzon et al., 2003). At the time they were conducted, the specimens were identified as Cynopoecilus melanotaenia (Regan, 1912), however, after a taxonomic revision made by Costa (2002) and in accordance with their geographic range, this species is now defined as Cynopoecilus multipapillatus Costa, 2002. Two recent studies focused on the diet (Laufer et al., 2009), and the relationships between food web structure and body size (Arim et al., 2010) of $C$. melanotaenia and three other rivulids. No previous study aimed to analyze reproductive aspects of $C$. melanotaenia and this study represents the first investigation about reproductive biology of this species.

Feeding and reproduction are important aspects of fish biology that directly affect population structure. Each species has different adaptations to increase its reproductive success (Nikolskii, 1969), thus knowledge on fecundity and spawning type, contributes with studies on natural history, and can provide baselines for population management strategies (Lowe-McConnell, 1999).

Considering the unique biological characteristics of rivulid species, vulnerability to habitat loss and the scarcity of biological information on most species, this study was conducted to characterize the diet and reproduction of $C$. melanotaenia. We predict that the feeding and reproductive strategies of C. melanotaenia would resemble those of other fish species inhabiting ephemeral environments.

\section{Material and Methods}

Fish samples were taken from a 250 ha area of intermittent

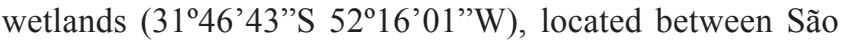
Gonçalo channel and Pelotas stream, State of Rio Grande do Sul, southern Brazil (Fig. 1). This area remains flooded during 6-8 months per year, from late fall and early winter (MayJune) to late spring and early summer (November-December). These wetlands are characterized by a silt substrate, turbid and shallow waters that do not exceed $60 \mathrm{~cm}$ depth, and a high density of macrophytes. The area is currently used for cattle ranching.

A total of three samples were taken during the initial phase of flooding (May and June 2005), and the drying phase (September 2006) to avoid negative impacts, such as reduction on C. melanotaenia populations in the study area. Fishes were captured actively using hand nets $(60 \times 50 \mathrm{~cm}, 2 \mathrm{~mm}$ mesh) during $30 \mathrm{~min}$. Caught specimens were fixed in $10 \%$ formalin and kept in 70\% alcohol until the laboratory analysis. Specimens were identified according to Costa (2002c) and voucher specimens were deposited in the fish collection of Departamento de Zoologia e Botânica, IBILCE/UNESP, Brazil (DZSJRP 12379-12381).

Measurements of total length (mm), total weight (g), sex, stomach repletion degree (SRD), fat accumulation degree (FAD), gonadal development stage (GDS) and gut length ( $\mathrm{mm}$ ) were taken from each specimen.

Stomach repletion was classified visually in three categories: degree 1 (empty), degree 2 (partially full) and degree 3 (full). The gut (stomach and intestine) were removed from the visceral cavity, weighed and kept in 70\% alcohol for further analysis of 

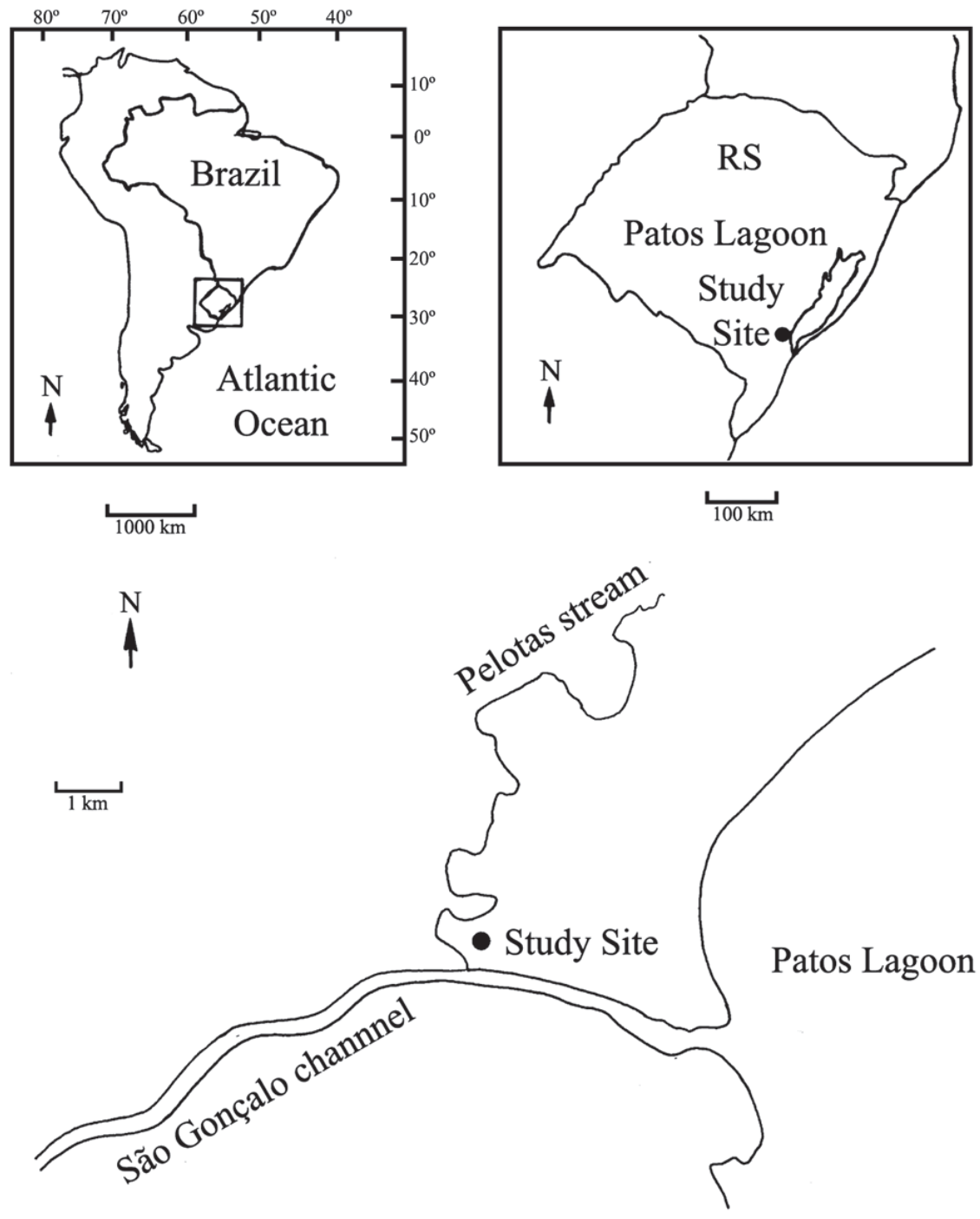

Fig. 1. Map of study area showing sampling location for Cynopoecilus melanotaenia between the São Gonçalo channel and Pelotas stream, State of Rio Grande do Sul (RS), Brazil.

the content. The visceral cavity was examined visually and the degree of accumulated fat was registered, considering: degree 1 (no fat), degree 2 (partially with fat) and degree 3 (full). The gonadal maturation stages were defined macroscopically according to oocyte's appearance, color, vascularization and transparency of the gonads, in the following categories: stage A (immature), stage B (maturing or resting), stage C (mature) and stage D (spent) (Vazzoler, 1996). The feeding activity and reproductive dynamics was verified analyzing the frequencies of SRD and FAD degrees with contingency tables and tested by chi-square (Zar, 2010). Differences between the proportions of males and females in the population were tested with chisquare, and the average length between the sexes was compared using t-test (Zar, 2010).

The diet was analyzed by examination of the gastrointestinal contents using the frequency of occurrence (FO) and numeric method (Bowen, 1992). Food items were identified up to the lowest taxonomic level possible according to Borror \& Delong (1969), Needhan \& Needhan (1982), Stehr (1991), Fernández \& Domínguez (2001) and Costa et al. (2006). Correlation between the diet of males and females was tested with the Spearman's rank correlation test using FO values and by graphical analysis of frequency and dominance of food items. A positive and significant value for Spearman's coefficient is expected when items occur in the same order of importance in the stomachs of both males and females. An item was considered dominant in a stomach when it prevailed over the others. To verify the relationship between the intestine length and diet, the intestinal quotient (IQ) was calculated using the formula IQ $=\mathrm{IL} / \mathrm{TL}$, where IL is the intestine length and TL the total fish length (Barbieri et al., 1994).

Body condition of C. melanotaenia was assessed by an analysis of covariance to evaluate differences in weight (dependent variable) between sexes (factors), using the total length as covariate. The level of significance was $\alpha=5 \%$ in all analysis. 
To assess fecundity, ovaries of mature females (stage C) were removed from the visceral cavity, weighted and kept in Gilson's solution until complete detachment of oocytes from epithelial and ovarian follicles. The total count of oocytes (n) was performed under a stereomicroscope with $16 \mathrm{x}$ magnification, and 100 of these oocytes were randomly selected and measured with an ocular micrometer $(10 \mathrm{x}$ magnification) to determine oocyte's diameter classes. This information was used to assess the type of spawning of the species and the diameter at which the oocytes become mature. Total fecundity was estimated using the volumetric method (Vazzoler, 1996). Individual fecundity was obtained using the formula $\mathrm{N}=\mathrm{n} * \mathrm{P} / 100$, where $\mathrm{n}$ is the total number of oocytes counted in the sample and $\mathrm{P}$ is the percentage of oocytes at the diameter at which they initiate the ripening process, in relation to the total number of oocytes (n) (Vazzoler, 1996). Frequency (\%) of oocytes distributions were calculated according to its diameter. Ovaries with similar diameter distributions were pooled to calculate the average frequency of oocytes by diameter class. According to Vazzoler (1996), this methodology allows the inference of the degree of development of the ovaries, which the advanced mode corresponds to the group of most developed oocytes. In addition, the number of modes indicates the type of spawning of the species, which corresponds to batches of developing oocytes into distinct phases. Relationships between individual fecundity and total length, and fecundity and total weight, were represented by an ordinary regression model given by $\mathrm{F}=\mathrm{A}+\mathrm{BX}$, where $\mathrm{F}$ represents fecundity (dependent variable), $\mathrm{X}$ the variable considered, in this case length or weight (independent variable), A the numerical value of the intercept and B the slope; estimated by the method of least squares after logarithmic transformation of the data (Sparre \& Venema, 1997).

\section{Results}

A total of 263 specimens were collected (182 males and 81 females) and a significant difference in sex ratio of 2:1 was encountered $\left(\chi^{2}=38.78 ; \mathrm{DF}=1 ; \mathrm{P}<0.01\right)$. Total length ranged between 16 to $43 \mathrm{~mm}$ in males and 14 to $34 \mathrm{~mm}$ in females. The results of the t-test indicated significant differences in length distributions between the sexes: $\left(x_{\text {males }}=24.98 \pm 0.33 \mathrm{~mm}\right.$ $\left.[\mathrm{SE}] ; x_{\text {females }}=23.66 \pm 5.2 \mathrm{~mm}[\mathrm{SE}] ; \mathrm{t}=2.02 ; \mathrm{DF}=238 ; \mathrm{P}=0.04\right)$ (Fig. 2). The annual fishes Austrolebias nigrofasciatus Costa \& Cheffe, 2001 and A. wolterstorffi (Ahl, 1924), and the nonannual fishes Mimagoniates inequalis (Eigenmann, 1911) (Characidae), Callichthys callichthys (Linnaeus, 1758) (Callichthyidae) and Phalloceros caudimaculatus (Hensel, 1868) (Poeciliidae) were also collected with C. melanotaenia.

The stomachs of most individuals were partially filled with food (45\%), followed by full (30\%) and empty (25\%) stomachs with significant differences between SRD frequencies $\left(\chi^{2}=\right.$ 17.62, $\mathrm{DF}=2, \mathrm{P}<0.001)$. A total of 133 males and 22 females had gonads in maturation (B) and 49 males and 59 females in the mature stage $(\mathrm{C})$. There were significant differences in the degree of accumulated fat in the visceral cavity $\left(\chi^{2}=205.26\right.$, $\mathrm{DF}=2, \mathrm{P}<0.001)$, where most individuals did not contain fat (73\%), and a much smaller proportion of individuals had the cavity partially filled (23\%) and the cavity filled with fat (3\%).

The analysis of 233 gastrointestinal contents revealed a diet consisted of 26 food items, in which 25 and 19 items were present in the diet of males and females, respectively (Table 1). In both sexes, the most consumed items in terms of frequency of occurrence were Cladocera, Diptera larvae (Chaoboridae, Culicidae, Syrphidae, but mainly Chironomidae), Amphipoda, Ostracoda, and insects parts, indicating an invertivorous diet. Cladocera and Cladocera/ Diptera (larvae) were frequent and dominant items in the diet of males and females, respectively (Fig. 3). Lepidophagy was registered only in male's diet. Diet of males and females were correlated $\left(r_{s}=0.52 ; P=0.005\right)$, suggesting that there were no differential preferences for the items consumed between sexes. The intestinal quotient was estimated at $0.03 \mathrm{~mm}$.

Analysis of body condition showed a significant interaction in the weight-length relation (Table 2), indicating a higher slope for females $(b=3.92)$ than males $(b=2.63)$ (Fig. 4).

Fecundity was estimated from the analysis of 59 pairs of mature ovaries. The number of mature oocytes (up to $551 \mu \mathrm{m}$ diameter) ranged from 2 to 157 (mean, $19 \pm 26[\mathrm{SD}]$ ), corresponding to females of 23 and $32 \mathrm{~mm}$ total length, respectively. The diameter of oocytes ranged from 61.2 to $1,101.6 \mu \mathrm{m}$ (mean, $211.7 \mu \mathrm{m} \pm 259[\mathrm{SD}]$ ) and three groups were determined according to its frequency distributions: group 1 $(n=9)$ : ovaries that contain oocytes in final stages of maturation; group $2(n=39)$ : ovaries that contains mature oocytes in intermediate stages of maturation and group $3(\mathrm{n}=$ 11): ovaries that contain mature oocytes in last stages of maturation (Fig. 5). The grouping analysis showed that the spawning was fractional, as evidenced by the presence of two modes in the frequency distribution of oocytes. The

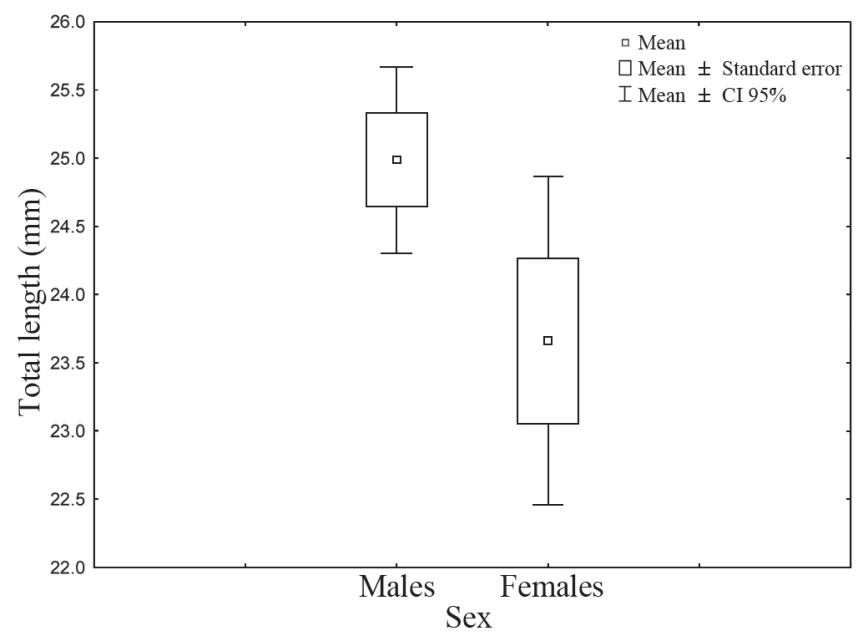

Fig. 2. Average, standard error and confidence interval (95\%) for the lengths of males and females of Cynopoecilus melanotaenia from wetlands between São Gonçalo channel and Pelotas stream, during May and June 2005, and September 2006. 
Table 1. Number of analyzed stomachs (N), richness of food items consumed (S), frequency of occurrence and dominance of each food item in the stomachs of males and females of Cynopoecilus melanotaenia from wetlands between São Gonçalo channel and Pelotas stream, during May and June 2005, and September 2006.

\begin{tabular}{|c|c|c|c|c|c|}
\hline \multirow{2}{*}{\multicolumn{2}{|c|}{ Food Items }} & \multicolumn{2}{|c|}{ Males $(\mathrm{N}=167 ; \mathrm{S}=25)$} & \multicolumn{2}{|c|}{ Females $(\mathrm{N}=66 ; \mathrm{S}=19)$} \\
\hline & & Occurrence $(\%)$ & Dominance $(\%)$ & Occurrence $(\%)$ & Dominance $(\%)$ \\
\hline \multicolumn{6}{|c|}{ Vegetal Origin } \\
\hline 1 & Unicellular algae - diatoms & - & - & $1(0.02)$ & - \\
\hline 2 & Filamentous algae & $3(0.02)$ & - & $1(0.02)$ & - \\
\hline 3 & \multicolumn{2}{|l|}{ Animal Origin } & $1(0.60)$ & $2(0.03)$ & $1(1.52)$ \\
\hline 4 & Protozoa & $1(0.01)$ & - & $4(0.06)$ & - \\
\hline 5 & Rotifera & $1(0.01)$ & - & $5(0.08)$ & - \\
\hline 6 & Nematoda & $2(0.01)$ & - & $2(0.03)$ & - \\
\hline 7 & Mollusca - Gastropoda & $1(0.01)$ & $1(0.60)$ & $4(0.06)$ & - \\
\hline \multicolumn{5}{|c|}{ Insects } & - \\
\hline 9 & Coleoptera & $16(0.10)$ & $8(4.79)$ & $1(0.02)$ & - \\
\hline 10 & Diptera (larvae) & $89(0.53)$ & $34(20.36)$ & $42(0.64)$ & $17(25.76)$ \\
\hline 11 & Diptera (adults) - Culicidae & $3(0.02)$ & $2(1.20)$ & $1(0.02)$ & - \\
\hline 12 & Ephemeroptera (nymphs and adults) & $16(0.10)$ & $12(7.19)$ & $1(0.02)$ & - \\
\hline 13 & Hemiptera - Auchenorrhyncha & $2(0.01)$ & $1(0.60)$ & $2(0.03)$ & - \\
\hline 14 & Hemiptera - Heteroptera & $2(0.01)$ & $2(1.20)$ & - & - \\
\hline 15 & Hymenoptera (adults) - Formicidae & $1(0.01)$ & - & - & - \\
\hline 16 & Lepidoptera (larvae) & $1(0.01)$ & $1(0.60)$ & - & - \\
\hline 17 & Odonata (nymphs) & $3(0.02)$ & $1(0.60)$ & $1(0.02)$ & $1(1.52)$ \\
\hline 18 & Plecoptera (nymphs) - Grypopterygidae & $1(0.01)$ & - & - & - \\
\hline 19 & Trichoptera (adults and cases) & $8(0.05)$ & $4(2.40)$ & $1(0.02)$ & - \\
\hline \multirow[t]{3}{*}{20} & Thysanoptera (adults) & $1(0.01)$ & - & - & - \\
\hline & Insect fragments & $32(0.19)$ & $11(6.59)$ & $25(0.38)$ & $12(18.18)$ \\
\hline & \multicolumn{5}{|l|}{ Crustacea } \\
\hline & Amphipoda - Gammaridea & $3(0.02)$ & $2(1.20)$ & $20(0.30)$ & $13(19.70)$ \\
\hline 22 & Cladocera & $127(0.76)$ & $72(43.11)$ & $53(0.80)$ & $17(25.76)$ \\
\hline 23 & Copepoda & $26(0.16)$ & - & $11(0.17)$ & - \\
\hline 24 & Isopoda & $4(0.02)$ & $4(2.40)$ & $4(0.06)$ & $3(4.55)$ \\
\hline 25 & Ostracoda & $62(0.37)$ & $9(5.39)$ & $16(0.24)$ & $2(3.03)$ \\
\hline 26 & Fish (scales) & $5(0.03)$ & - & - & - \\
\hline & Sediment & $1(0.01)$ & - & - & - \\
\hline
\end{tabular}

relationship between fecundity and total length $(\mathrm{mm})$ and weight $(\mathrm{g})$, were represented by the equations, $\mathrm{y}=167.43+$ $7.08 \times(r=0.75)$ and $y=-33.79+256.6 x(r=0.78)$, respectively.

\section{Discussion}

In this study, C. melanotaenia coexisted with Austrolebias nigrofasciatus and A. wolterstorffi, two Rivulidae species endangered in Brazil (Rosa \& Lima, 2008). D’Anatro \& Loureiro (2005) recorded C. melanotaenia inhabiting ponds containing three species of Austrolebias in many localities in eastern wetlands of Uruguay and suggested that ecological interactions, such as competition and predation, may be possible mechanisms responsible for creating variability and diversity in their system. Volcan et al. (2009) also recorded a syntopic occurrence of $C$. melanotaenia with $A$. nigrofasciatus and $A$. wolterstorffi in southern Brazil. Besides these two species of annual fishes, three species of non-annual fishes were recorded with $C$. melanotaenia in this study. Ephemeral environments with a high density of macrophytes, such as the wetland under study, are inhabited by multiple species of small fishes. Possible explanations for the preference of these habitats by small fishes are that they offer shelter, protection from predators and a high availability of food resources like insect larvae and small crustaceans (Junk et al., 1989; Esteves \& Galetti Jr., 1995; Esteves, 1996; Winemiller \& Jepsen, 1998; Motta \& Uieda, 2005). Other studies also reported the occurrence of C. melanotaenia with non-annual fishes (VazFerreira et al., 1966; Quintela et al., 2007) and, probably, the coexistence of different species in transient pools may be due to connection of water bodies during rainfall events (Errea \& Danulat, 2001).

Data on sex ratio can provide important information about population dynamics and varies throughout the life cycle due to successive events, which act differently on individuals of each sex (Vazzoler, 1996). The fluctuations in the sex ratio in a population may be a common phenomenon without effects on the persistence of local populations, but can provide information about susceptibility of individuals at a particular time or region. In the present study there was a ratio of 2 males to 1 female whereas Laufer et al. (2009) found a proportion of 1:1 in a population in Uruguay. Differences in sex ratio may increase competition and agonistic behaviors within unbalanced populations, especially in species in which males defend their territory during the courtship behavior, such as annual fishes (see forward discussion about lepidophagy). 
Table 2. Covariance analysis of weight (dependent variable) and total length (TL) (covariate) of males and females of Cynopoecilus melanotaenia from wetlands between São Gonçalo channel and Pelotas stream, during May and June 2005, and September 2006. Ln = Natural logarithm.

\begin{tabular}{lllllc}
\hline Sources of variation & \multicolumn{1}{c}{ SQ } & DF & \multicolumn{1}{c}{ MS } & F & P \\
\hline Ln TL & 96.257 & 1 & 96.257 & 1348.749 & $<0.001$ \\
Sex & 3.698 & 1 & 3.698 & 51.818 & $<0.001$ \\
Ln TL * Sex & 3.754 & 1 & 3.754 & 52.608 & $<0.001$ \\
Error & 16.843 & 236 & 0.071 & & \\
\hline
\end{tabular}

The maturation of the gonads and reproductive activity involves the use of energy reserves obtained from the food ingested and deposited in different parts of the body (Vazzoler, 1996). Most analyzed specimens of C. melanotaenia did not show fat in the visceral cavity. This is probably related to its short life cycle, fast growth, early sexual maturation and continuous reproduction, as demonstrated also by Arenzon et al. $(1999,2001)$ to C. multipapillatus, considering that rivulids whole life cycle occurs in ephemeral ponds (Laufer $e t$ al., 2009). Thus, analysis of the degree of stomach repletion and accumulated fat appears to indicate that during its short life cycle, the species has an intense feeding activity to quickly convert food into energy to the maturation of gametes, taking advantage of propitious environmental conditions.

Diet analysis indicated that C. melanotaenia is an invertivorous and generalist predator that exploits the entire water column, consuming preferably small crustaceans and aquatic immature insects. These results were similar to those found in other rivulids: Simpsonichthys boitonei (Shibatta \& Rocha, 2001), Rivulus pictus (Shibatta \& Bennemann, 2003) and three species of Austrolebias and C. melanotaenia (Laufer et al., 2009). According to Laufer et al. (2009) and Polaèik \& Reichard (2010), the generalist feeding strategy is expected to occur in annual fishes that inhabit ephemeral habitats with variable conditions, because any diet specialization is likely to incur significant costs due to temporal and spatial variations in prey availability. In fact, these statements appear to agree with the expected feeding habits of closely related species inhabiting environments with similar characteristics regardless of annual or non-annual condition. Cyprinodontiformes species that occurs in ephemeral habitats are generalists feeders (Rivulidae: annual fish Simpsonichthys boitonei (Shibatta \& Rocha, 2001), annual fishes Austrolebias spp. and C. melanotaenia (Laufer et al., 2009), non-annual fish Rivulus pictus (Shibatta \& Bennemann, 2003); Nothobranchiidae: annual fish Nothobranchius spp. (Polaèik \& Reichard, 2010), while species inhabiting running water streams are herbivorous (Poeciliidae: Phalloceros caudimaculatus, Poecilia vivipara, Phalloptychus januarius, and Anablepidae: Jenynsia lineata (Aranha \& Caramaschi, 1999), all non-annual fishes), species that occurs on permanent rainforest ponds feed on allochthonous material such as terrestrial insects (Aplocheilidae: annual fish Aphyosemion gardneri (Akpan et al., 2006), and salt marshes species feed on mangrove-related items (e.g., Polychaeta and small marine crustaceans) like non-annual fishes Rivulus marmoratus (Taylor, 1992) and Fundulus spp. (Baker-Dittus, 1978)). Moreover, the diet of C. melanotaenia is consistent with the low intestinal quotient found in this study. According to Nikolsky (1963), species with short intestine in relation of the body length have carnivorous diet. Carnivory in rivulids has been also found by other authors (Taylor, 1992; Shibatta \& Rocha, 2001; Shibatta \& Bennemann, 2003; Laufer et al., 2009). Although diet between males and females was not
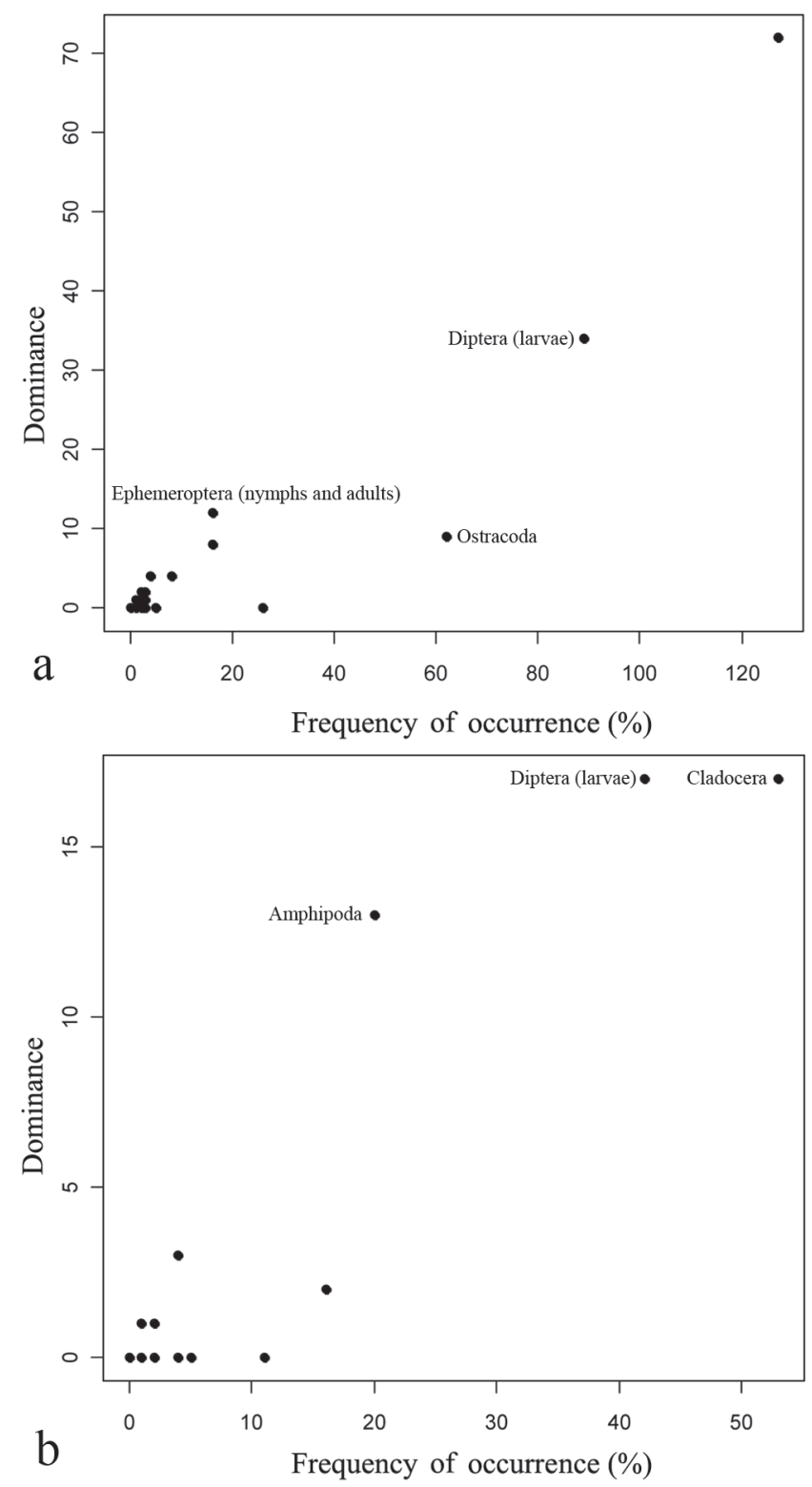

Fig. 3. Diet of males (a) and females (b) of Cynopoecilus melanotaenia from wetlands between São Gonçalo channel and Pelotas stream, during May and June 2005, and September 2006 , according to the frequency of occurrence and dominance of food items. 
different, it was observed that males of $C$. melanotaenia consumed a larger quantity of food than females and also ingested a greater number of preys. Laufer et al. (2009) found the same pattern of feeding behavior in this species. Probably the sexual size dimorphism is a determinant factor in the capture of preys. Like males of other Aplocheiloidei (Costa, 2006a), males of Cynopoecilus are larger than females (Arenzon et al., 1999, 2001; Laufer et al., 2009) and probably have a major capacity as predators, ingesting more quantity of food than females. Arim et al. (2010) found a positive relationship between trophic position and body size in four annual fishes (including $C$. melanotaenia), and argue that these relationships between the trophic structures with body size are well explained by gape limitation, where larger organisms had access to more energy from the environment. In a review of sexual dimorphism, Shine (1989) argues that dietary differences between males and females is almost inevitable if the sexes differ much in body size and that this is a widespread phenomenon among animals.

According to Shibatta \& Rocha (2001), lepidophagy on rivulids is a strong evidence of intra- or interspecific aggressive behavior, exhibited by territorial males (Shibatta, 2006). In this study, consumption of fish scales was documented in five male specimens of $C$. melanotaenia. Laufer et al. (2009) did not found fish scales in gut contents in the specimens they analyzed. Comparing the sex ratio information obtained in the present study ( 2 males to 1 female) to this population in Uruguay (1:1) (Laufer et al., 2009) it seems plausible to infer that agonistic behavior between males for territory defense occurred in the present study.

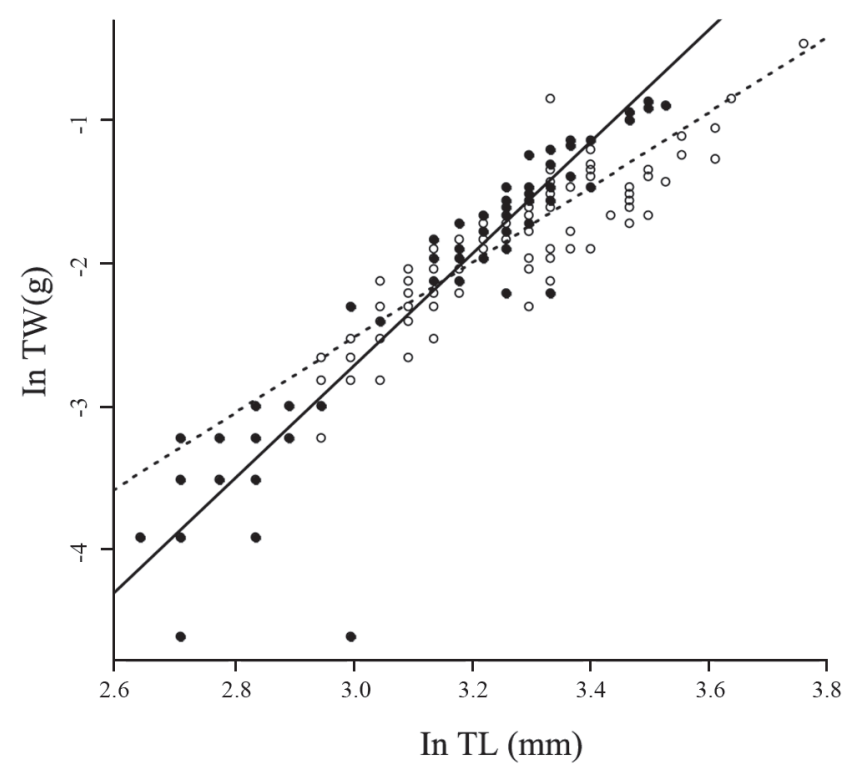

Fig. 4. Linear regressions between total length (TL) and total weight (TW) of males (open symbol, dotted line) and females (black symbol, solid line) of Cynopoecilus melanotaenia from wetlands between São Gonçalo channel and Pelotas stream, during May and June 2005, and September 2006. $\ln (\mathrm{TW})_{\text {males }}=2.63 \ln (\mathrm{TL})$ $10.41, \mathrm{R}^{2}=0.82 ; \ln (\mathrm{TW})_{\text {females }}=3.92 \ln (\mathrm{TL})-14.49, \mathrm{R}^{2}=0.87$.
Lepidophagy suggest that agonistic behavior may occur in places with higher density of males but it remains unclear if it occurred between males or males-females. Experimental studies are recommended with observation in the wild or in captivity (aquarium) to verify how agonistic behavior act on this species.

The gonads of most males were maturing (stage B) while females were mature (stage C). According to Arenzon et al. (1999) the gonadal development of C. multipapillatus, a close relative species, is interrupted only during the dry season when the adults die. In the present study, the significant interaction in the weight-length relation between sexes indicates differences in the slopes of linear regressions and thus a similar increase in length, although females have a higher weight gain than males. In fact, the higher slope for females can be related to the greater weight of ovaries in relation to the testicles (Nikolsky, 1963) in individuals of the same length but with mature gonads.

Cynopoecilus melanotaenia in its natural habitat has low fecundity with 2 to 157 oocytes (diameters up to 1,101.6 $\mu \mathrm{m}$ ). Arenzon et al. (1999) pointed out a similar variability in the number of mature oocytes from 49 to 219 (diameters up to $1,375 \mu \mathrm{m})$ in C. multipapillatus. Unfortunately, there are no
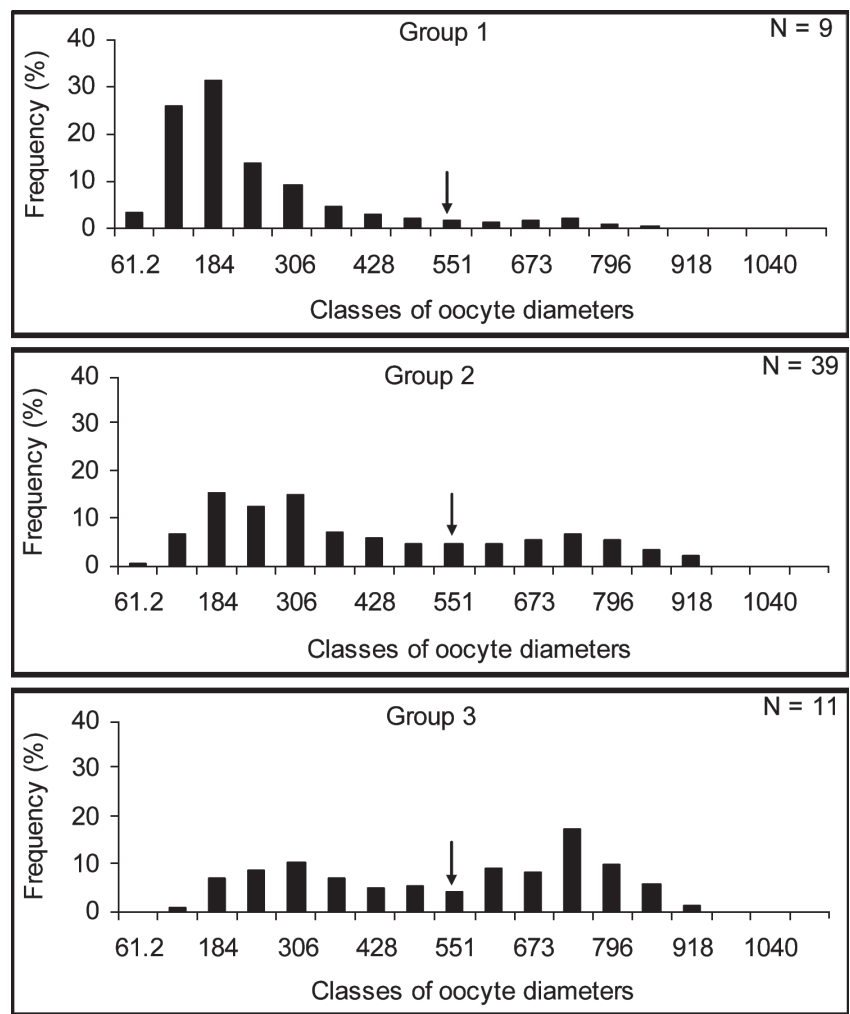

Fig. 5. Individuals of Cynopoecilus melanotaenia grouped by frequencies (\%) of distribution of oocyte diameters $(\mu \mathrm{m})$, from wetlands between São Gonçalo channel and Pelotas stream, during May and June 2005, and September 2006. Arrows indicate the size in which the oocytes become mature. 
other reproductive studies with fecundity data of closely related species for comparative purposes. Fecundity can vary between species and populations, reflecting strategies in the life cycle (Nikolskii, 1969). Annual fishes, which live in ephemeral environments, have small body size, early sexual maturation, continuous reproduction and production of multiple small nests, may be considered typical examples of opportunistic species (Winemiller, 1989), which corresponds to some biological characteristics found in the rivulid $C$. melanotaenia. According to Winemiller \& Rose (1992), fishes exhibiting the opportunistic strategy seem to be associated with very shallow habitats which are exposed to intense predation or unpredictable spatial and temporal variations. Moreover, the type of spawning of $C$. melanotaenia was fractional, also considered as a strategy to increase the chance of survival to prolonged depletions and stochastic water level (Shibatta, 2005), conditions commonly found in ephemeral habitats. Arenzon et al. $(1999,2001)$ also found this type of spawning in C. multipapillatus without a defined breeding season over a long period in accordance with environmental characteristics. Fractional spawning was also observed in $S$. boitonei (Shibatta, 2005) and A. charrua (Arezo et al., 2007). Fractional spawning is usually associated with unstable environments, such as the ephemeral habitats where $C$. melanotaenia were studied, which ensures greater food supply for larvae and juveniles of fish species with long reproductive period and represents an adaptation to exploit available resources (Nikolskii, 1969; Vazzoler, 1996). Moreover, Cynopoecilus and Campellolebias species spawn in the midwater (Costa, 1995, 2002c) and they are the unique rivulids with modifications in the structure of the anal fin for internal fertilization (Costa, 2003). According to Thibault \& Schultz (1978), once internal fertilization evolved, various modifications in the reproductive system are possible, including oocyte's number and size. Thus, species with internal fertilization can produce few but large oocytes, as seen in C. melanotaenia and C. multipapillatus (Arenzon et al., 1999) and also in other Cyprinodontiformes, such as Poeciliidae members (Thibault \& Schultz, 1978), a reproductive strategy that can increase their reproductive success. According to Burns \& Weitzman (2005), internal fertilization also represents an advantage for fish species that lives in acid waters which avoids sperm death that have a short survival in these water conditions. Two non-annual species recorded in the wetland studied also has internal fertilization, Phalloceros caudimaculatus (Poeciliidae) (Rosen \& Tucker, 1961) and Mimagoniates inequalis (Characidae) (Burns et al., 1995). Thus, reproductive aspects seem to be related with environmental characteristics imposed to species and not to annual and non-annual conditions, similarly to diet aspects found.

Annual fishes are found in ephemeral environments often subject to human activities, such as cattle ranching and rice cultures that lead to habitat loss. According to Maltchik et al. (2010) approximately $90 \%$ of the wetlands have disappeared in southern Brazil. These authors pointed out that faster degradation and insufficient scientific knowledge about species emphasize the urgency of ecological studies to provide scientific support to develop conservation programs in these environments. The present study highlights important aspects of the life history of $C$. melanotaenia such as feeding and reproductive strategies in their natural environment. The species consumed preferably small crustaceans and aquatic immature insects and has an opportunistic reproductive strategy with fractional spawning, which aims to increase the chances of survival of individuals that inhabit ephemeral environments often subject to strong human pressures. This was the first study involving reproductive aspects with C. melanotaenia. Further studies must focus on the relationship between available resources and body sizes which may clarify diet differences between sexes and also on experiments in order to evaluate intra- and interspecific behaviors. Such information can contribute to a better understanding of $C$. melanotaenia life cycle in their natural environment, improving knowledge about its biological aspects to guide conservation researchers and species management in the wild.

\section{Acknowledgements}

The authors thank the Museu de História Natural of the Universidade Católica de Pelotas (MUCPel) that gently provided the specimens of Cynopoecilus melanotaenia used in the present study, the Departament of Zoology at Universidade Estadual Paulista "Júlio de Mesquita Filho", Edilberto Giannotti for invertebrates identification, Jaime R. Somera for mapping the study area, Fabio C. Ferreira and César Cestari for helpful suggestions that improved the quality of this manuscript, and Sandra Bibiana Correa (Texas A\&M University) for reviewing the English.

\section{Literature Cited}

Akpan, B. E., R. P. King \& G. E. Jonathan. 2006. Diet of killifish Aphyosemion gardneri (Aplocheilidae) in a Nigerian rainforest pond. Acta Zoologica Sinica, 52: 669-675.

Aranha, J. M. R. \& E. P. Caramaschi. 1999. Estrutura populacional, aspectos da reprodução e alimentação dos Cyprinodontiformes (Osteichthyes) de um riacho do sudeste do Brasil. Revista Brasileira de Zoologia, 16: 637-651.

Arenzon, A., C. A. Lemos \& M. B. C. Bohrer. 2002. The influence of temperature on the embryonic development of the annual fish Cynopoecilus melanotaenia (Cyprinodontiformes, Rivulidae). Revista Brasileira de Biologia, 62: 743-747.

Arenzon, A., A. C. Peret \& M. B. C. Bohrer. 1999. Reproduction of the annual fish Cynopoecilus melanotaenia (Regan, 1912) in a temporary water body in Rio Grande do Sul, Brazil. Hydrobiologia, 411: 65-70.

Arenzon, A., A. C. Peret \& M. B. C. Bohrer. 2001. Growth of the annual fish Cynopoecilus melanotaenia (Regan, 1912) based in a temporary water body population in Rio Grande do Sul state, Brazil (Cyprinodontiformes, Rivulidae). Revista Brasileira de Biologia, 61: 117-123. 
Arenzon, A., R. F. Pinto, P. Colombo \& M. T. Raya-Rodriguez. 2003. Assessment of the freshwater annual fish Cynopoecilus melanotaenia as a toxicity test organism using three reference substances. Environmental Toxicology and Chemistry, 22: 21882190.

Arezo, M. J., S. D’Alessandro, N. Papa, R. Sá \& N. Berois. 2007. Sex differentiation pattern in the annual fish Austrolebias charrua (Cyprinodontiformes: Rivulidae). Tissue Cell, 39: 89-98.

Arim, M., S. R. Abades, G. Laufer, M. Loureiro \& P. A. Marquet. 2010. Food web structure and body size: trophic position and resource acquisition. Oikos, 119: 147-153.

Baker-Dittus, A. M. 1978. Foraging patterns of three sympatric killifish. Copeia, 1978: 383-389.

Barbieri, G., A. C. Peret \& J. R. Verani. 1994. Notas sobre a adaptação do trato digestivo ao regime alimentar em espécies de peixes da região de São Carlos (SP). I. Quociente Intestinal. Revista Brasileira de Biologia, 54: 63-69.

Borror, D. J. \& D. M. Delong. 1969. Introdução ao estudo de insetos. São Paulo, Edgard Blücher Ltda, 653p.

Bowen, S. H. 1992. Quantitative description of the diet. Pp. 325336. In: Nielsen, L. A. \& D. L. Johnson (Eds.). Fisheries techniques. Bethesda, American Fisheries Society, 462p.

Burns, J. R., S. H. Weitzman, H. J. Grier \& N. A. Menezes. 1995. Internal fertilization, testis and sperm morphology in glandulocaudinae fishes (Teleostei: Characidae: Glandulocaudinae). Journal of Morphology, 224: 131-145.

Burns, J. R. \& S. H. Weitzman. 2005. Insemination in ostariophysan fishes. Pp. 107-134. In: Uribe, M. C. \& H. J. Grier (Eds.). Viviparous fishes. Florida, New Life International, 603p.

Costa, C., S. Ide \& C. E. Simonka. 2006. Insetos imaturos - metamorfose e identificação. Ribeirão Preto, Holos, 249p.

Costa, W. J. E. M. 1990a. Análise fillogenética da família Rivulidae (Cyprinodontiformes, Aplocheiloidei). Revista Brasileira de Biologia, 50: 65-82.

Costa, W. J. E. M. 1995. Revision of the neotropical annual fish genus Cynopoecilus (Cyprinodontiformes: Rivulidae). Copeia, 1995: 456-465.

Costa, W. J. E. M. 1998. Phylogeny and classification of Rivulidae revisited: evolution of annualism and miniaturization in rivulid fishes (Cyprinodontiformes: Aplocheiloidei). Journal of Comparative Biology, 3: 33-92.

Costa, W. J. E. M. 2002a. Monophyly and phylogenetic relationships of the neotropical annual fish genera Austrolebias and Megalebias (Cyprinodontiformes, Rivulidae). Copeia, 2002: 916-927.

Costa, W. J. E. M. 2002b. Peixes anuais brasileiros: diversidade e conservação. Curitiba, UFPR, 240p.

Costa, W. J. E. M. 2002c. The annual fish genus Cynopoecilus (Cyprinodontiformes: Rivulidae): taxonomic revision, with descriptions of four new species. Ichthyological Exploration of Freshwaters, 13: 11-24.

Costa, W. J. E. M. 2003. Family Rivulidae (South American annual fishes). Pp. 526-548. In: Reis, R. E., S. O. Kullander \& C. J. Ferraris Jr. (Orgs.). Check List of the Freshwater Fishes of the South and Central America. Porto Alegre, Edipucrs, 742p.

Costa, W. J. E. M. 2006a. Descriptive morphology and phylogenetic relationships among species of the Neotropical annual killifish genera Nematolebias and Simpsonichthys (Cyprinodontiformes: Aplocheiloidei: Rivulidae). Neotropical Ichthyology, 4: 1-26.

Costa, W. J. E. M. 2006b. Taxonomy and phylogenetic relationships among species of the seasonal, internally inseminating, South American killifish genus Campellolebias (Teleostei:
Cyprinodontiformes: Rivulidae), with the description of a new species. Zootaxa, 1227: 31-55.

Costa, W. J. E. M. 2008. Catalog of Aplocheiloid killifishes of the world. Rio de Janeiro, UFRJ, 127p.

D'Anatro, A. \& M. Loureiro. 2005. Geographic variation in Austrolebias luteoflamulatus Vaz-Ferreira, Sierra \& Scaglia (Cyprinodontiformes, Rivulidae). Journal of Fish Biology, 67: 849-865.

Errea, A. \& E. Danulat. 2001. Growth of the annual fish, Cynolebias viarius (Cyprinodontiformes), in the natural habitat compared to laboratory conditions. Environmental Biology of Fishes, 61: 261-268.

Esteves, K. E. 1996. Feeding ecology of three Astyanax species (Characidae, Tetragonopterinae) from a floodplain lake of MogiGuaçú River, Paraná River basin, Brazil. Environmental Biology of Fishes, 46: 83-101.

Esteves, K. E. \& P. M. Galetti Jr. 1995. Food partitioning among some characids of a small Brazilian floodplain lake from the Paraná River basin. Environmental Biology of Fishes, 42: 375 389.

Fernández, H. R. \& E. Dominguez. 2001. Guía para la determinación de los artrópodos bentónicos sudamericanos. Tucumán, UNT, $282 \mathrm{p}$.

Hertwig, S. T. 2007. Phylogeny of the Cyprinodontiformes (Teleostei, Atherinomorpha): the contribution of cranial soft tissue characters. Zoologica Scripta, 37: 141-174.

Hrbek, T. \& A. Larson. 1999. The evolution of diapause in the killifish family Rivulidae (Atherinomorpha, Cyprinodontiformes): a molecular phylogenetic and biogeographic perspective. Evolution, 53: 1200-1216.

Junk W., P. B. Bayley \& R. E. Sparks. 1989. The flood pulse concept in river-floodplain systems. Canadian Journal of Fisheries and Aquatic Sciences, 106: 110-127.

Laufer, G., M. Arim, M. Loureiro, J. M. Piñeiro-Guerra, S. ClavijoBaquet \& C. Fagúndez. 2009. Diet of four annual killifishes: an intra and interspecific comparison. Neotropical Ichthyology, 7: 77-86.

Lowe-Mcconnell, R. H. 1999. Estudos ecológicos em comunidades de peixes tropicais. São Paulo, EDUSP, 534p.

Maltchik, L., L. E. K. Lanés, C. Stenert \& E. S. F. Medeiros. 2010. Species-area relationship and environmental predictors of fish communities in coastal freshwater wetlands of southern Brazil. Environmental Biology of Fishes, 88: 25-35.

Motta, R. L. \& V. S, Uieda. 2005. Food web structure in a tropical stream ecosystem. Austral Ecology, 30: 58-73.

Murphy, W. J. \& G. E. Collier. 1996. Phylogenetic relationships within the Aplocheiloid fish genus Rivulus (Cyprinodontiformes, Rivulidae): implications for Caribbean and Central American biogeography. Molecular Biology and Evolution, 13: 642-649.

Murphy, W. J., J. E. Thomerson \& G. E. Collier. 1999. Phylogeny of the neotropical killifish family Rivulidae (Cyprinodontiformes, Aplocheiloidei) inferred from mitochondrial DNA sequences. Molecular Phylogenetics and Evolution, 13: 289-301.

Needham, J. G. \& P. R. Needham. 1982. Guía para el studio de los seres vivos de las aguas dulces. Barcelona, Reverte, 131p.

Nikolskii, G. V. 1969. Theory of fish population dynamics: as the biological background for rational exploitation and management of fishery resources. Edinburgh, Oliver and Boyd Ltda, 321p.

Nikolsky, G. V. 1963. The ecology of fishes. London, Academic Press, 353p. 
Parenti, L. R. 1981. A phylogenetic and biogeographic analysis of cyprinodontiforms fishes (Teleostei, Atherinomorpha). Bulletin of the American Museum of Natural History, 168: 335-557.

Polaèik, M. \& M. Reichard. 2010. Diet overlap among three sympatric African annual killifish species Nothobranchius spp. from Mozambique. Journal of Fish Biology, 77: 754-768.

Quintela, F. M., R. A. Porciuncula, M. V. L. Condini, J. P. Vieira \& D. Loebmann. 2007. Composição da ictiofauna durante o período de alagamento em uma mata paludosa da planície costeira do Rio Grande do Sul, Brasil. Pan-American Journal of Aquatic Sciences, 2: 191-198.

Reis, R. E., Z. M. S. Lucena, C. A. S. Lucena \& L. R. Malabarba. 2003. Peixes. Pp. 117-145. In: Fontana, C. S., G. A. Bencke \& R. E. Reis (Eds.). Livro Vermelho da Fauna Ameaçada de Extinção no Rio Grande do Sul. Porto Alegre, Edipucrs. 632p.

Rosa, R. S. \& F. C. T. Lima. 2008. Peixes. Pp. 9-285. In: Machado, A. B. M., G. M. Drummond \& A. P. Paglia (Eds.). Livro vermelho da fauna brasileira ameaçada de extinção. Brasília, Ministério do Meio Ambiente, 906p.

Rosa, R. S., N. A. Menezes, H. A. Britski, W. J. E. M. Costa \& F. Groth. 2003. Diversidade, padrões de distribuição e conservação dos peixes da caatinga. Pp. 135-181. In: Leal, I. R., M. Tabarelli \& J. M. C. Silva (Orgs.). Ecologia e conservação da Caatinga. Recife, Ed. Universitária da UFPE, 822p.

Rosen, D. E., A. Tucker. 1961. Evolution of secondary sexual characters and sexual behavior patterns in a family of viviparous fishes (Cyprinodontiformes: Poeciliidae). Copeia, 1961: 201212.

Shibatta, A. O. 2005. Reprodução do pirá-brasília, Simpsonichthys boitonei Carvalho (Cyprinodontiformes, Rivulidae), e caracterização de seu habitat na Reserva Ecológica do Instituto Brasileiro de Geografia e Estatística, Brasília, Distrito Federal, Brasil. Revista Brasileira de Zoologia, 22: 1146-1151.

Shibatta, A. O. 2006. Comportamento social do pirá-brasília, Simpsonichthys boitonei Carvalho (Cyprinodontiformes, Rivulidae). Revista Brasileira de Zoologia, 23: 375-380.

Shibatta, A. O. \& S. T. Bennemann. 2003. Plasticidade alimentar em Rivulus pictus Costa (Osteichthyes, Cyprinodontiformes, Rivulidae) de uma pequena lagoa em Brasília, Distrito Federal, Brasil. Revista Brasileira de Zoologia, 20: 615-618.

Shibatta, A. O. \& A. J. A. Rocha. 2001. Alimentação em machos e fêmeas de Simpsonichthys boitonei Carvalho (Cyprinodontiformes, Rivulidae). Revista Brasileira de Zoologia, 18: 381-385.
Shine, R. 1989. Ecological causes for the evolution of sexual dimorphism: a review of the evidence. The Quarterly Review of Biology, 64: 419-461.

Sparre, P. \& S. C. Venema. 1997. Introdução à avaliação de mananciais de peixes tropicais, Parte 1. Roma, FAO, 404p.

Stehr, F. W. 1991. Immature insects, 2v. Dubuque, Kundal/Hunt Publishing Company, 992p.

Taylor, D. S. 1992. Diet of the killifish Rivulus marmoratus collected from land crab burrows, with further ecological notes. Environmental Biology of Fishes, 33: 389-393.

Thibault, R. E. \& R. J. Schultz. 1978. Reproductive adaptations among viviparous fishes (Cyprinodontiformes: Poeciliidae). Evolution, 32: 320-333.

Volcan, M. V., L. E. K. Lanés, A. C. Gonçalves. 2009. Threatened fishes of the world: Austrolebias nigrofasciatus Costa and Cheffe 2001 (Cyprinodontiformes, Rivulidae). Environmental Biology of Fishes, 86: 443-444.

Vaz-Ferreira, R., B. Sierra de Soriano \& J. S. Señorans. 1966. Integracion de La fauna de vertebrados em algunas masas de agua dulce temporales del Uruguay. Compendios de Trabajo del Departamento de Zoología Vertebrados, 25: 1-16.

Vazzoler, A. E. A. M. 1996. Biologia da reprodução de peixes teleósteos: Teoria e Prática. Maringá, Eduem, 169p.

Winemiller, K. O. 1989. Patterns of variation in life history among South American fishes in seasonal environments. Oecologia, 81: 225-241.

Winemiller, K. O. \& D. B. Jepsen. 1998. Effects of seasonality and fish movement on tropical river food webs. Journal of Fish Biology, 53 (Supplement A): 267-296.

Winemiller, K. O. \& K. A. Rose. 1992. Patterns of life-history diversification in North American fishes: implications for population regulation. Canadian Journal of Fisheries and Aquatic Science, 49: 2196-2218.

Wourms, J. P. 1972. Developmental biology of annual fishes. III. Pre-embryonic and embryonic diapause of variable duration in the eggs of annual fish. Journal of Experimental Zoology, 182: $389-414$.

Zar, J. H. 2010. Biostatistical analysis, 5th ed. New Jersey, PrenticeHall, 944p.

Accepted December 20, 2010 Published March 31, 2011 